\title{
LIVING WILLS IN THE NURSING PROFESSION: KNOWLEDGE AND BARRIERS
}

\author{
Marta Elena Losa Iglesias ${ }^{1}$, Ricardo Becerro de Bengoa Vallejo ${ }^{2}$
}

\begin{abstract}
The aims of this study were to understand Spanish nurses' knowledge about living wills and legal regulations and to explore their experiences, needs and challenges in these situations using quantitative and qualitative approaches.

The first part of the study was a descriptive survey administered to a convenience sample of nurses (454 individuals) who worked in hospitals and other primary care clinics in the Principality of Asturias in northern Spain. The survey tested their knowledge of living wills and related major legal issues. At the end of the survey, the nurses were asked to provide a personal email address if they were interested in participating in a personal interview. In the second part of this study, we used a qualitative phenomenological approach based on Husserl's framework.

The results indicate that nurses are not sufficiently knowledgeable about the use of LWD in clinical practise. As a consequence, they are unable to support patient autonomy in health care treatment decisions.
\end{abstract}

Key words: Living wills; nursing knowledge; nursing ethics

\section{Las Directivas Anticipadas en la profesión de enfermería: el conocimiento y las barreras}

Resumen: Los objetivos de este estudio fueron comprender el conocimiento de enfermeras españolas sobre las directivas anticipadas y las regulaciones legales, y explorar sus experiencias, necesidades y desafíos en aquellas situaciones, utilizando métodos cuantitativos y cualitativos. La primera parte del estudio consistió en una encuesta descriptiva administrada a una muestra de enfermeras (454 individuos) que trabaja en hospitales y otros centros de atención primaria en el Principado de Asturias, en el norte de España. El estudio evaluó sus conocimientos sobre las directivas anticipadas y consideró temas legales relacionados. Al final del estudio, a las enfermeras se les preguntó si proporcionarían una dirección de correo electrónico personal para participar en una entrevista personal. En la segunda parte de este estudio se utilizó un enfoque fenomenológico cualitativo, basado en el marco de Husserl.

Los resultados indicaron que las enfermeras no tienen los conocimientos suficientes sobre el uso de LWD en la práctica clínica. Como consecuencia, son incapaces de apoyar la autonomía del paciente en las decisiones de tratamiento de cuidado de la salud.

Palabras clave: directivas anticipadas, conocimientos de enfermería, ética de enfermería

\section{As Diretivas Antecipadas na profissáo de enfermagem: o conhecimento e as barreiras}

Resumo: Os objetivos deste estudo foram compreender o conhecimento de enfermeiras espanholas sobre as diretivas antecipadas e as regulamentaçôes legais, e explorar suas experiências, necessidades e desafios naquelas situaçôes, utilizando métodos quantitativos e qualitativos. A primeira parte do estudo consistiu numa enquete descritiva administrada numa amostra de enfermeiras ( 454 indivíduos) que trabalham em hospitais e outros centros de atenção primária no Principado de Astúrias, ao norte da Espanha. O estudo avaliou seus conhecimentos sobre as diretivas antecipadas e considerou temas legais relacionados. Ao final do estudo, às enfermeiras foi perguntado se proporcionariam uma direção de correio eletrônico pessoal para participar de uma entrevista pessoal. Na segunda parte deste estudo foi utilizado um enfoque fenomenológico qualitativo, baseado no marco de Husserl.

Os resultados indicaram que as enfermeiras não têm os conhecimentos suficientes sobre o uso de LWD na prática clínica. Como consequência, são incapazes de apoiar a autonomia do paciente nas decisôes de tratamento de cuidado em saúde.

Palavras-chave: diretivas antecipadas, conhecimentos das enfermeiras, ética de enfermagem

\footnotetext{
${ }^{1}$ Full Professor, Facultad de Ciencias de la Salud, Universidad Rey Juan Carlos, Madrid, Spain

Correspondence: marta.losa@urjc.es

${ }^{2}$ Full Professor, Escuela de Enfermería, Fisioterapia y Podología, Universidad Complutense de Madrid, Spain
} 


\section{Introduction}

Given today's societal demands, there is a clear need for patients to create a living will, which is a document designed to enforce a patient's rights to respect for his or her personality, human dignity, privacy and personal autonomy, as well as confidentiality in the handling of his or her clinical history(1). The bioethical principle of patient autonomy and patients' rights and obligations regarding medical information are well recognised, and medical doctors and nurses play an important role in supporting patients' autonomy in health care treatment decisions and respecting their personal wishes at the end of life(2-6).

The U.S. experience with 'living wills' begins in the mid-1960s. In 1967, the Euthanasia Society of America first launched the idea of a written document, a 'testament' in which the patient could express the way he wanted to be treated when he could not decide by himself(7).

Two years later, in 1969, Kutner first used the term 'living will' in the USA, arguing that a competent adult's wishes for his or her future care should be recorded and respected(8). The issue was raised again in 1976, when the parents of Karen Quinlan successfully applied to have the ventilator removed from their daughter, who had been diagnosed as brain-stem dead, thanks to a New Jersey Supreme Court ruling that noted the 'right to die with dignity and in peace'. This ruling prompted many ethical committees to enact living will statutes in the USA(9).

Nevertheless, living wills remain controversial. For instance, formal religious bodies have debated how to relate the autonomy-empowering advance health care directives to their own religious perspectives(10). Nurses have a duty to be aware of current ethical issues and to have some understanding of the issues raised by living wills before treating a patient who has a living will so that they can accept without prejudice each patient's wishes, even when they do not agree with them $(10,11)$.

The current situation in Spain is similar to that of the USA in the early 1990s: a significant legislative development has taken place (BOE Law 41/2002)(12), but little real implementation has resulted in the health professions and the general population. Therefore, the risk of making mistakes is high(13). The nursing profession in Spain needs to assume a leading role in this area, as nurses in other countries have done(14-16).

The aim

For the above reasons, the aims of this study were to understand Spanish nurses' knowledge about living wills and legal regulations and to explore their experiences, needs and challenges in these situations using quantitative and qualitative approaches.

\section{Materials and methods}

\section{Design and setting}

The first part of the study was a descriptive survey administered to a convenience sample of nurses who worked in hospitals and other primary care clinics in the Principality of Asturias in northern Spain. The survey tested their knowledge of living wills and related major legal issues. At the end of the survey, the nurses were asked to provide a personal email address if they were interested in participating in a personal interview. In the second part of this study, we used a qualitative phenomenological approach based on Husserl's framework(17).

\section{Participants}

The Official and Professional College of Nurses in the Principality of Asturias, Spain, is the institution through which all nurses in this state are registered. There are 5997 registered nurses in the College's files. The study took place between 29 June 2010 and 1 May 2011.

\section{Data collection}

The anonymous survey instrument, which was piloted and validated for Spanish health professionals in a previous study(18) consisted of 16 items, each with three possible answers (Yes, No, 
I don't know), and aimed to evaluate the respondents' knowledge of the most relevant aspects of living wills and attitudes about their use in clinical practice. The survey included five categories of statements about relevant aspects of living wills: their use in clinical practice $(\mathrm{U})$, document content (D), conceptual definition (C), procedures and registration $(\mathrm{P})$, and legal aspects $(\mathrm{L})$ (Table $1)$.

Selected socio-demographic data (age, gender, years working as a nurse, place of employment and previous training in living wills) were collected to determine if these variables were related to the survey results.

The second part of the study comprised an open question at the end of the questionnaire asking about the respondent's experiences, needs and barriers. The open question started with the following sentence, followed by Morse's(19) counsel: "Do you want or need to share your personal reflections and experiences about living wills?"

\section{Data analysis}

Statistical analysis

The Statistical Package for the Social Sciences version 17.0 for Windows (SPSS Inc., Chicago, IL) was used to analyse the survey data. Descriptive statistics (means, SD, and percentages) were used to describe the nurse sample and all answers to the survey.

The following statistical procedures were employed: chi-squared test, Student's t-test, and ANOVA. Statistical significance was determined using the p-value and the $95 \%$ confidence inter$\operatorname{val}(\mathrm{CI})$.

\section{Organisation of qualitative fieldwork}

Only one researcher was responsible for the data collection, treatment and preliminary analysis. After the preliminary analysis, the results were analysed and discussed with all authors in joint sessions. In case of differences of opinion, a consensus between the authors was reached by discussion. The analysis was performed on the basis of the Giorgi method. The data analysis process began with the descriptive content to obtain the meaning units, then proceeded to a detailed analysis before the final phenomenological reduction to identify groups of statements sharing the same meaning. The data validation method used involved three steps: a) cross-triangulation by the researcher, b) analysis of the survey's answers, and c) comparison of the findings with the scientific literature.

\section{Ethical considerations}

Ethical approval for the study was obtained from the Ethical Committee of the Official and Professional College of Nurses in the Principality of Asturias. The participants were asked to read and discuss the consent form prior to completing the survey and agreeing to the interview. Confidentiality was assured, all identifiers were removed from the questionnaires, all data were kept secure, and pseudonyms were used.

\section{Results}

\section{Characteristics of the sample}

The demographic and professional characteristics of the sample population are summarised in Table 2. The sample consisted of 454 nurses, most of whom were female $(94.27 \%)$. This gender distribution was similar to the overall gender distribution of all registered nurses in the Professional Colleges of Spain. The mean age of the nurse respondents was 36.2 years (SD 8.86), and the mean total years of employment in nursing was 8.4 (SD 7.4). Their primary areas of practise were geriatrics $(14.8 \%)$, emergency room $(12 \%)$, primary care $(12 \%)$, critical care $(10.8 \%)$, and surgery $(7.3 \%)$. Most $(55.5 \%)$ of the respondents had been working in their current ward for less than 10 years. Only $23 \%$ of the nurses had received previous training about living wills (Table 1). 


\begin{tabular}{|c|c|c|c|}
\hline Statement & Yes & No & Category \\
\hline $\begin{array}{l}\text { 1. Living wills are instructions } \\
\text { on the actions to take in the } \\
\text { last stage of life if we cannot } \\
\text { express the instructions } \\
\text { ourselves. }\end{array}$ & $\mathrm{X}$ & & $\mathrm{C}$ \\
\hline $\begin{array}{l}\text { 2. Living wills are based on the } \\
\text { right to patient autonomy. }\end{array}$ & $\mathrm{X}$ & & C \\
\hline $\begin{array}{l}\text { 3. Living wills must assign a } \\
\text { delegate person. }\end{array}$ & & $\mathrm{X}$ & $\mathrm{D}$ \\
\hline $\begin{array}{l}\text { 4. The patient's family must } \\
\text { agree with the contents of a } \\
\text { living will for it to be valid. }\end{array}$ & & $\mathrm{X}$ & $\mathrm{L}$ \\
\hline $\begin{array}{l}\text { 5. The living will document } \\
\text { can be formalised before a } \\
\text { notary. }\end{array}$ & & $\mathrm{X}$ & $\mathrm{P}$ \\
\hline $\begin{array}{l}\text { 6. The living will document can } \\
\text { include aspects against law. }\end{array}$ & & X & $\mathrm{D}$ \\
\hline $\begin{array}{l}\text { 7. The living will is directed to } \\
\text { the physician responsible for } \\
\text { the patient's care. }\end{array}$ & $\mathrm{X}$ & & $\mathrm{L}$ \\
\hline $\begin{array}{l}\text { 8. The living will document has } \\
\text { a unique format designed by } \\
\text { the Department of Health. }\end{array}$ & & $\mathrm{X}$ & $\mathrm{P}$ \\
\hline $\begin{array}{l}\text { 9. The attending physician has } \\
\text { a moral duty to follow the } \\
\text { instructions of the living } \\
\text { will. }\end{array}$ & $\mathrm{X}$ & & $\mathrm{U}$ \\
\hline $\begin{array}{l}\text { 10. The living will document is } \\
\text { regulated by law in Spain. }\end{array}$ & $\mathrm{X}$ & & $\mathrm{L}$ \\
\hline $\begin{array}{l}\text { 11. Living wills may include } \\
\text { instructions about organ } \\
\text { donation. }\end{array}$ & $\mathrm{X}$ & & $\mathrm{D}$ \\
\hline $\begin{array}{l}\text { 12. The living will is only valid if } \\
\text { the patient is enrolled in the } \\
\text { registry of the Department } \\
\text { of Health. }\end{array}$ & & $\mathrm{X}$ & $\mathrm{P}$ \\
\hline $\begin{array}{l}\text { 13. Living wills may specify } \\
\text { situations in which the } \\
\text { execution of the will is } \\
\text { temporarily suspended. }\end{array}$ & $\mathrm{X}$ & & $\mathrm{L}$ \\
\hline $\begin{array}{l}\text { 14. The attending physician is } \\
\text { required by law to follow } \\
\text { the instructions of the living } \\
\text { will. }\end{array}$ & & $\mathrm{X}$ & $\mathrm{L}$ \\
\hline $\begin{array}{l}\text { 15. If the attending physician } \\
\text { knows the patient's will, he } \\
\text { has a moral duty to follow } \\
\text { it, even if there is no written } \\
\text { document. }\end{array}$ & $\mathrm{X}$ & & $\mathrm{U}$ \\
\hline $\begin{array}{l}\text { 16. If the attending physician } \\
\text { cannot follow the will of the } \\
\text { patient, he has a moral duty } \\
\text { to transfer care to another } \\
\text { physician, nurse, etc. }\end{array}$ & $\mathrm{X}$ & & $\mathrm{U}$ \\
\hline
\end{tabular}

Table 1. Questionnaire about living wills with correct answers and categories. (C) Conceptual Definition; (D) Document Content; (L) Legal Aspects; (P) Procedures and Registration; (U) Use in Clinical Practice.

\section{Results of the Questionnaire about Living Wills}

The percentages of correct, incorrect, and "don't know" answers are shown in Table 3. The percentages of correct answers for each category were as follows: conceptual definition (80.75\%), document content $(55.5 \%)$, use in clinical practice (54.4\%), legal aspects (43.2\%), procedures and registration $(32.2 \%)$.

In the procedures and registration category, only $7.5 \%$ of the nurses knew that the "living will is only valid if the patient is enrolled in the registry of the Department of Health", and only 12.3\% knew that a living will can have more than one format. For the questions about legal aspects of living wills, the lowest percentage of correct answers (9\%) was observed for the question of whether the attending physician is required by law to follow the instructions of the living will. Associations between the level of knowledge about the Questionnaire about Living Wills and age, gender and previous training

No differences based on gender or training was found for any of the responses analysed. Significant differences were observed between respondents of different ages for the questions about formalising the Living Will Document (LWD) before a notary $(\mathrm{p}<0.001)$ and whether a living will must assign a delegate person $(\mathrm{p}=0.048)$.

\section{Results of the Questionnaire about Living Wills by nursing field}

Statistically significant differences in knowledge of LWDs were observed between nurses working in different fields. Significant differences by nursing field were observed in knowledge about the need to formalise the living will before a notary $(\mathrm{p}<0.001)$, whether the LWD is regulated by law in Spain $(\mathrm{p}=0.004)$, the need to assign a delegate person $(\mathrm{p}=0.032)$, and the need to be enrolled in the registry of the Department of Health $(\mathrm{p}=0.011)$.

Table 4 shows the analysis of non-correct (wrong or "don't know") answers by category in the different nursing fields. Table 5 shows the analysis 


\begin{tabular}{|l|r|r|}
\hline Characteristics & Frequency & $\%$ \\
\hline Gender & & \\
\hline Female & 428 & 94.27 \\
Male & 26 & 5.73 \\
\hline Age & & \\
\hline $22-30$ & 162 & 35.7 \\
$31-40$ & 141 & 31.1 \\
41-50 & 100 & 22.1 \\
$51-60$ & 45 & 9.9 \\
$\geq 61$ & 4 & 0.9 \\
\hline Nursing field & & \\
\hline Cardiology & 19 & 4.2 \\
Critical care & 49 & 10.8 \\
Gastroenterology & 5 & 1.1 \\
Emergency room & 55 & 12.1 \\
Geriatrics & 67 & 14.8 \\
Gynaecology & 5 & 1.1 \\
Haematology & 16 & 3.5 \\
Internal medicine & 25 & 5.5 \\
Nephrology & 5 & 1.1 \\
Neurology & 7 & 1.5 \\
Oncology & 12 & 2.6 \\
Ophthalmology & 3 & 0.7 \\
Operating room & 24 & 5.3 \\
Palliative care & 105 & 23.1 \\
Paediatrics & 24 & 5.3 \\
Primary care & 9 & 2.0 \\
Psychiatry & 53 & 12.3 \\
Radiology & 8 & 1.8 \\
Sports medicine & 11 & 2.4 \\
Surgery & 2 & 0.4 \\
Trauma & 33 & 7.3 \\
Urology & 13 & 2.9 \\
\hline Years working in the same ward & 6 & 1.3 \\
\hline$\leq 10$ & & \\
$11-20$ & 252 & 55.6 \\
21-30 & & \\
$\geq 31$ & & \\
\hline Previous Training in living wills & 0.6 \\
\hline No & \\
Yes & \\
\hline
\end{tabular}

Table 2. Characteristics of the sample. of non-correct (wrong or uncertain) answers for all of the questions among nurses in specific fields (geriatrics, palliative care, oncology, primary care). Geriatrics, oncology, gastroenterology, radiology, and urology nurses showed higher percentages of non-correct answers. Particularly, more than half of the nurses working in each of these specific nursing fields reported ignorance about document content, legal aspects and procedures and registration. Psychiatric and surgical nurses had the lowest percentages of non-correct answers.

\section{Qualitative analysis of the open question}

Finally, of the 454 nurses who responded to the questionnaire, only $23(5 \%)$ expressed their feelings in the open question. The highest percentages of nurses responding to the open question worked in surgery (13.04\%) and critical care (13.04\%).

The themes identified from the responses to the open question included uncertainty about patients' rights and the need for training.

\section{Uncertainty about patients' rights}

One of the most common themes of the answers to the open question was fear of inadequacy; the survey made nurses more aware of their limited knowledge about living wills, and they worried that this had diminished the quality of their nursing care: "Now I feel unsure because I don't know anything about living wills, so how can I help my patients?" Responses like, "Now I fear that patients will ask me about their rights before they die, and I will not know how to deal with it," and, "It is a taboo subject; it scares me," reaffirm the potential barriers to understanding this sensitive but important issue.

The participants reported that it is important to be informed and up to date on the legislative aspects of patients' rights: "It's amazing how fast they change the law.... I had no idea of these changes. Perhaps the hospital should inform us of them better." 
Living wills in the nursing profession: knowledge and barriers - Marta Losa, Ricardo Becerro de Bengoa

\begin{tabular}{|c|c|c|c|}
\hline Statement & Correct & Incorrect & I don't know \\
\hline $\begin{array}{l}\text { Living wills are instructions on the actions to take in the last stage of } \\
\text { life if we cannot express the instructions ourselves. }\end{array}$ & $399(87.9 \%)$ & $7(1.5 \%)$ & $48(10.6 \%)$ \\
\hline Living wills are based on the right to patient autonomy. & $334(73.6 \%)$ & $24(5.3 \%)$ & $96(21.1 \%)$ \\
\hline Living wills must assign a delegate person. & $131(28.9 \%)$ & $77(17 \%)$ & $245(54 \%)$ \\
\hline $\begin{array}{l}\text { The patient's family must agree with the contents of a living will for } \\
\text { it to be valid. }\end{array}$ & $329(72.5 \%)$ & $28(6.2 \%)$ & $97(21.4 \%)$ \\
\hline The living will document can be formalised before a notary. & $348(76.7 \%)$ & $106(23.3 \%)$ & $0(0 \%)$ \\
\hline Living wills must assign a delegate person. & $255(56.2 \%)$ & $28(6.2 \%)$ & $171(37.7 \%)$ \\
\hline $\begin{array}{l}\text { The living will is directed to the physician responsible for the patient's } \\
\text { care. }\end{array}$ & $187(39.2 \%)$ & $87(19.2 \%)$ & $189(41.6 \%)$ \\
\hline $\begin{array}{l}\text { The living will document has a unique format designed by the De- } \\
\text { partment of Health. }\end{array}$ & $46(12.3 \%)$ & $139(30.6 \%)$ & $259(57 \%)$ \\
\hline $\begin{array}{l}\text { The attending physician has a moral duty to follow the instructions } \\
\text { of the living will. }\end{array}$ & $329(72.5 \%)$ & $24(5.3 \%)$ & $101(22.2 \%)$ \\
\hline The living will document is regulated by law in Spain. & $325(71.6 \%)$ & $6(1.3 \%)$ & $121(26.7 \%)$ \\
\hline Living wills may include instructions about organ donation. & $302(66.5 \%)$ & $10(2.2 \%)$ & $142(31.3 \%)$ \\
\hline $\begin{array}{l}\text { The living will is only valid if the patient is enrolled in the registry of } \\
\text { the Department of Health. }\end{array}$ & $34(7.5 \%)$ & $118(26 \%)$ & $300(66.1 \%)$ \\
\hline $\begin{array}{l}\text { Living wills may specify situations in which the application of the } \\
\text { will is temporarily suspended. }\end{array}$ & $108(23.8 \%)$ & $29(6.4 \%)$ & $317(69.8 \%)$ \\
\hline $\begin{array}{l}\text { The attending physician is required by law to follow the instructions } \\
\text { of the living will. }\end{array}$ & $41(9 \%)$ & $232(51.1 \%)$ & $181(39.9 \%)$ \\
\hline $\begin{array}{l}\text { If the attending physician knows the patient's will, he has a moral } \\
\text { duty to follow it, even if there is not a written document. }\end{array}$ & $160(35.2 \%)$ & $106(23.3 \%)$ & $188(41.4 \%)$ \\
\hline $\begin{array}{l}\text { If the attending physician cannot follow the will of the patient, he } \\
\text { has a moral duty to transfer care to another physician, nurse, etc. }\end{array}$ & $252(55.5 \%)$ & $16(3.5 \%)$ & $186(41 \%)$ \\
\hline
\end{tabular}

Table 3. The study sample's answers, in terms of counts and percentages, to the Questionnaire about Living Wills.

\section{Need for training}

Another important shortcoming that the nurses reported was the lack of training on living wills. They felt that hospitals and professional associations should conduct specific training on this topic: "I am totally unfamiliar with this issue, so a seminar could be helpful."

Additionally, nurses' feelings of shame as a result of their ignorance were apparent in statements like, "I need and would like more training. I'm really ashamed."

The feeling of shame was mitigated by knowledge on the subject in the trained nurses, but the knowledgeable or trained nurses were upset with their fellow nurses because these nurses delegated to them the responsibility of giving information on living wills to the patients: "I know I am able to provide good information to patients, but I'm an- gry that my co-workers delegate that responsibility to me."

\section{Discussion}

This study shows that Spanish nurses are not sufficiently knowledgeable about the living will statute in Spain. Particularly, a lack of knowledge about legal aspects (only $43.2 \%$ of the nurses were correctly informed) and about the procedures and registration of LWDs (only 32.2\% of the nurses knew how to proceed) were apparent among the nurses in our sample. A high percentage of nurses $(80.75 \%)$ knew the conceptual definition of LWD, but nearly half of the sample $(46 \%)$ were unaware of how to use them in clinical practice. Almost one fourth of the nurses $(23 \%)$ in this sample had participated in specific training programs about LWDs, but these educational pro- 
Acta Bioethica 2013; 19 (1): 113-123

\begin{tabular}{|c|c|c|c|c|c|}
\hline Nursing field & $\begin{array}{l}\text { Conceptual } \\
\text { definition }\end{array}$ & $\begin{array}{l}\text { Document } \\
\text { content }\end{array}$ & $\begin{array}{l}\text { Use in clinical } \\
\text { practice }\end{array}$ & Legal aspects & $\begin{array}{l}\text { Procedures and } \\
\text { registration }\end{array}$ \\
\hline Cardiology & $15.8 \%$ & $38.6 \%$ & $49.2 \%$ & $58.9 \%$ & $63.1 \%$ \\
\hline Critical Care & $21.4 \%$ & $51.7 \%$ & $44.9 \%$ & $59.2 \%$ & $69.4 \%$ \\
\hline Digestive & $20.0 \%$ & $66.7 \%$ & $53.3 \%$ & $68.0 \%$ & $73.3 \%$ \\
\hline Emergency room & $18.2 \%$ & $53.3 \%$ & $48.5 \%$ & $58.9 \%$ & $64.8 \%$ \\
\hline Geriatrics & $27.3 \%$ & $56.2 \%$ & $50.8 \%$ & $61.2 \%$ & $69.2 \%$ \\
\hline Gynaecology & $0 \%$ & $40.0 \%$ & $53.3 \%$ & $56.0 \%$ & $66.7 \%$ \\
\hline Haematology & $15.6 \%$ & $54.2 \%$ & $35.5 \%$ & $55.0 \%$ & $72.9 \%$ \\
\hline Internal medicine & $12.0 \%$ & $53.3 \%$ & $46.7 \%$ & $53.0 \%$ & $72.0 \%$ \\
\hline Nephrology & $10.0 \%$ & $46.7 \%$ & $46.7 \%$ & $56.9 \%$ & $66.7 \%$ \\
\hline Neurology & $14.7 \%$ & $38.1 \%$ & $42.9 \%$ & $50.3 \%$ & $66.7 \%$ \\
\hline Oncology & $37.5 \%$ & $58.3 \%$ & $44.4 \%$ & $61.7 \%$ & $69.5 \%$ \\
\hline Ophthalmology & $0 \%$ & $33.3 \%$ & $55.5 \%$ & $86.6 \%$ & $66.7 \%$ \\
\hline Operating room & $13.2 \%$ & $42.7 \%$ & $44.4 \%$ & $47.6 \%$ & $69.4 \%$ \\
\hline Palliative care & $20.9 \%$ & $37.5 \%$ & $44.4 \%$ & $49.1 \%$ & $58.3 \%$ \\
\hline Paediatrics & $16.7 \%$ & $40.7 \%$ & $44.4 \%$ & $62.0 \%$ & $63.0 \%$ \\
\hline Primary care & $18.8 \%$ & $53.0 \%$ & $44.0 \%$ & $55.7 \%$ & $69.1 \%$ \\
\hline Psychiatry & $0 \%$ & $25.0 \%$ & $20.6 \%$ & $44.9 \%$ & $29.2 \%$ \\
\hline Radiology & $40.9 \%$ & $66.6 \%$ & $60.6 \%$ & $69.1 \%$ & $72.7 \%$ \\
\hline Sports medicine & $0 \%$ & $33.3 \%$ & $66.7 \%$ & $50.0 \%$ & $66.7 \%$ \\
\hline Surgery & $15.0 \%$ & $38.4 \%$ & $30.3 \%$ & $47.9 \%$ & $69.7 \%$ \\
\hline Trauma & $15.4 \%$ & $43.6 \%$ & $43.6 \%$ & $53.9 \%$ & $69.2 \%$ \\
\hline Urology & $41.6 \%$ & $66.6 \%$ & $66.7 \%$ & $73.3 \%$ & $72.2 \%$ \\
\hline
\end{tabular}

Table 4. Non correct answers to the Questionnaire about Living Wills in all nursing fields by question category.

grams do not guarantee the implementation of a patient's living will in clinical practice. This result indicates the need for more effective ways of disseminating this important information, such as educational in-services targeted to the topic of legal advance directives and the patient's right to participate in personal health care treatment decisions.

Our sample comprised a fairly homogenous group with a similar profile to other national(20) and international studies(16) on living wills: most respondents were female, and the majority was younger than 50 years old.

Compared with the only other study in Spain analysing primary care professionals' knowledge and attitudes about LWDs, we found a similar conceptual definition of LWD, a higher percentage of correct answers about how to use LWDs in clinical practice and a lower percentage of correct answers regarding legal aspects and the procedures and registration of LWDs.

Similar to previous international studies(6), the results of this survey indicate that $30 \%$ of the respondents did not know or were uncertain about whether LWDs are regulated by law in Spain. In the procedures and registration category, only $7.5 \%$ of the nurses knew that a living will is valid even if the patient is not enrolled in the registry of the Department of Health, and only $12.3 \%$ knew that LWDs can have more than one format.

The role of the attending physician was one of the least well-understood topics among nurses, and although $72 \%$ of them knew that the attending physician has a moral duty to follow the instructions of the LWD, only $9 \%$ of the nurses knew that this is not required by law. Moreover, nearly 
half of the nurses were uncertain whether the attending physician has a moral duty to transfer responsibility to another heath care professional (e.g., another physician, a nurse) if he is unwilling or unable to follow the LWD. These data demonstrate the obvious potential for conflict between nurses and physicians. For example, in several studies nurses have expressed their concern about physicians' failure to respect living wills $(15,21,22)$, but nurses do not seem to assume the responsibility of talking to the physician about the moral duty of transferring responsibility for the patient's care to another health care professional if he or she does not wish to respect the mandates of the living will. Moreover, in the qualitative analysis, the knowledgeable nurses were upset with their co-workers who delegated to them the responsibility of discussing living

\begin{tabular}{|c|c|c|c|c|}
\hline Statement & Geriatrics $(n=67)$ & $\begin{array}{l}\text { Palliative care } \\
(\mathrm{n}=24)\end{array}$ & Oncology $(\mathrm{n}=12)$ & $\begin{array}{l}\text { Primary care } \\
(\mathrm{n}=56)\end{array}$ \\
\hline $\begin{array}{l}\text { Living wills are instructions on the actions } \\
\text { to take in the last stage of life if we cannot } \\
\text { express the instructions ourselves. }\end{array}$ & $13(19.4 \%)$ & $3(12.5 \%)$ & $3(25.0 \%)$ & $6(10.7 \%)$ \\
\hline $\begin{array}{l}\text { Living wills are based on the right to } \\
\text { patient autonomy. }\end{array}$ & $19(35.2 \%)$ & $7(29.2 \%)$ & $6(50.0 \%)$ & $14(25 \%)$ \\
\hline Living wills must assign a delegate person. & $51(76.1 \%)$ & $15(62.5 \%)$ & $8(66.6 \%)$ & $48(85.7 \%)$ \\
\hline $\begin{array}{l}\text { The patient's family must agree with the } \\
\text { contents of the living will for it to be valid. }\end{array}$ & $21(31.3 \%)$ & $5(20.8 \%)$ & $4(33.3 \%)$ & $12(21.4 \%)$ \\
\hline $\begin{array}{l}\text { The living will document can be for- } \\
\text { malised before a notary. }\end{array}$ & $14(20.9 \%)$ & $4(16.7 \%)$ & $3(25.0 \%)$ & $9(16.1 \%)$ \\
\hline Living wills must assign a delegate person. & $31(46.3 \%)$ & $6(25.0 \%)$ & $9(75.0 \%)$ & $24(42.9 \%)$ \\
\hline $\begin{array}{l}\text { The living will is directed to the physician } \\
\text { responsible for the patient's care. }\end{array}$ & $45(67.2 \%)$ & $12(50.0 \%)$ & $8(66.7 \%)$ & $38(67.9 \%)$ \\
\hline $\begin{array}{l}\text { The living will document has a unique } \\
\text { format designed by the Department of } \\
\text { Health. }\end{array}$ & $60(89.6 \%)$ & $17(70.8 \%)$ & $11(91.7 \%)$ & $52(92.9 \%)$ \\
\hline $\begin{array}{l}\text { The attending physician has a moral duty } \\
\text { to follow the instructions of the living will. }\end{array}$ & $24(30.8 \%)$ & $7(29.2 \%)$ & $3(25.0 \%)$ & $11(19.6 \%)$ \\
\hline $\begin{array}{l}\text { The living will document is regulated by } \\
\text { law in Spain. }\end{array}$ & $20(29.9 \%)$ & $6(25.0 \%)$ & $4(33.3 \%)$ & $14(25 \%)$ \\
\hline $\begin{array}{l}\text { Living wills may include instructions } \\
\text { about organ donation. }\end{array}$ & $31(66,5 \%)$ & $6(25.0 \%)$ & $4(33.3 \%)$ & $17(30.4 \%)$ \\
\hline $\begin{array}{l}\text { The living will is only valid if the patient is } \\
\text { enrolled in the registry of the Department } \\
\text { of Health. }\end{array}$ & $65(97,0 \%)$ & $21(87.5 \%)$ & $11(91.7 \%)$ & $55(98.2 \%)$ \\
\hline $\begin{array}{l}\text { Living wills may specify situations in } \\
\text { which the application of the will is tempo- } \\
\text { rarily suspended. }\end{array}$ & $56(83.6 \%)$ & $16(66.7 \%)$ & $10(83.3 \%)$ & $41(73.2 \%)$ \\
\hline $\begin{array}{l}\text { The attending physician is required by law } \\
\text { to follow the instructions of the living will. }\end{array}$ & $63(94.0 \%)$ & $20(83.3 \%)$ & $11(91.7 \%)$ & $51(91.1 \%)$ \\
\hline $\begin{array}{l}\text { If the attending physician knows the pa- } \\
\text { tient's will, he has a moral duty to follow } \\
\text { it, even if there is not a written document. }\end{array}$ & $46(68.7 \%)$ & $17(70.8 \%)$ & $7(58.3 \%)$ & $39(69.6 \%)$ \\
\hline $\begin{array}{l}\text { If the attending physician cannot follow } \\
\text { the will of the patient, he has a moral } \\
\text { duty to transfer care to another physician, } \\
\text { nurse, etc. }\end{array}$ & $32(47.8 \%)$ & $8(33.3 \%)$ & $6(50.0 \%)$ & $24(42.9 \%)$ \\
\hline
\end{tabular}

Table 5. Non correct answers to the Questionnaire about Living Wills in specific nursing fields. 
wills with patients. These findings also suggest that nurses usually assume a passive role. They feel that they are not prepared, and they usually delegate to others the task of providing information to patients about the benefits of drafting a living will to guide future health care treatment decisions.

Another important subject is the contradiction between the nurses' theoretical knowledge and their practical skills for following a LWD. Health care professionals have generally positive attitudes towards living wills(23), but fewer than $5 \%$ of hospital patients have written a living will; the documents often are not implemented as planned and are ignored during actual decision making(24-26). No differences in the knowledge of LWDs were observed that were related to the sex or training of the nurses, but differences by age were observed in the questions regarding the role of the notary and the need to assign a delegate person. Differences were also found between nurses in different fields regarding the role of the notary, the need to assign a delegate person, the requirement of being enrolled in the registry of the Department of Health and whether the LWD is regulated by law in Spain. Particularly relevant are the high rates of ignorance and uncertainty among the nursing fields that are more directly involved in end-of-life care: geriatrics, oncology and palliative care.

Qualitative research is well suited for understanding phenomena within their context and uncovering links among concepts and behaviours. The most important topics that nurses raised in the qualitative analysis were their uncertainly about patients' rights, the fear of having to inform a patient about a topic they did not understand well, and the absolute need for training on living wills. LWDs seem to be a sensitive subject for nursing professionals as many of them were reluctant to complete the questionnaire, and only $5 \%$ of them agreed to express their feelings in the open question. It is important for nurses and other health care professionals to recognise that the collection of information regarding the patient's use of a legal advance directive is a critical aspect of the Patient Self-Determination Act. If a nurse is not knowledgeable about the state's statutory scheme for legal advance directives, it will be difficult for him or her to serve as a patient's advocate regarding questions about patient autonomy and health care treatment decisions(27).

\section{Study limitations}

Some possible limitations of the study should be considered. First, the present study builds on selfreport data obtained by means of a cross-sectional design, which prevents us from drawing firm conclusions on the causality of the observed relationships. Other limitations of the study include a moderate response rate and a limited geographical area, although the characteristics of the sample are similar to the characteristics of the population of registered nurses in the Professional Colleges of Spain. On the other hand, as LWDs are a sensitive matter for some nurses, they may have been reluctant to complete the questionnaire.

Based on the present study, poor knowledge about living wills seems to be a substantial problem in healthcare, and further research needs to be done on possible interventions to address this problem. Healthcare organisations will have to promote accessible policies and procedures to warrant the implementation of patient self-determination in health care, particularly nurse-patient interactions. Our study is unique in addressing specific aspects of the LWD that need to be clarified and better taught.

\section{Conclusion}

Our results indicate that nurses are not sufficiently knowledgeable about the use of LWD in clinical practise. As a consequence, they are unable to support patient autonomy in health care treatment decisions. This study corroborates the utility of the questionnaire about the living will as a valid and reliable tool for measuring knowledge about LWDs and highlights the importance of implementing specific interventions to alleviate the shortcomings observed.

Fundings: This research did not receive specific funding. 
Living wills in the nursing profession: knowledge and barriers - Marta Losa, Ricardo Becerro de Bengoa

\section{References}

1. Bachiller A, Hernández de Miguel S, Martínez Queipo, M, et al. Testamento vital: la opinión médica en la provincia de Valladolid. Metas de Enfermería 2004; 7: 14-27.

2. American Nurses Association. Compendium of Position Statements on the Nurse's Role in End-of-Life Decisions. Washington, DC: American Nurses Association, 1992.

3. Fry ST. Autonomy, advocacy, and accountability: ethics at the bedside. In: Fowler MDM, Levine-Ariff J, eds. A Source Book for the Critical Care Nurse. Philadelphia, PA: Lippincott, 1987: 39-49.

4. Oddi LE. Enhancing patients' autonomy. Dimens Crit Care Nurs 1994; 13: 60-8.

5. Wiens AG. Patient autonomy in care: a theoretical framework for nursing. Journal of Professional Nursing 1993; 9: 95-103.

6. Weiler K, Eland J, Buckwalter KC. Iowa nurses' knowledge of living wills and perceptions of patient autonomy. Journal of Professional Nursing 1996; 12: 245-52.

7. Emanuel EJ, Emanuel LL. Living wills: past, present, and the future. Journal of Clinical Ethics 1990; 1: $9-20$.

8. Kutner L. Due process of euthanasia: the living will with a proposal. Indiana Law Journal 1969; $44: 539$.

9. Losa ME. Spanish and North American society and biomedical advances: comparative study. PhD Dissertation. Spain: Universidad de Oviedo; 2007.

10. Cowe F. Living wills: making patients' wishes known. Prof Nurse 1996; 11(6): 362-363.

11. Hanson LC, Rodgman E. The use of living wills at the end of life: a national study. Archives of Internal Medicine 1996; 156: 1018-1022.

12. Law 41/2002. Basic law regulating patient autonomy and the rights and obligations of clinical information and documentation. BOE núm. 274. Available at http://www.boe.es/boe/dias/2002/11/15/pdfs/A40126-40132.pdf (Accessed 25 July 2011).

13. Barrio IM, Simón P, Júdez J. From advance directives or living wills to advance care planning. Nurse Investigation 2004; (5): 1-9.

14. Blondeau D, Lavoie M, Valois P. The attitude of Canadian nurses towards advance directives. Nursing Ethics 2000; 7: 399 -411.

15. Hilden HM, Louhiala P, Honkasalo LM, et al. Finnish nurses' views on end-of-life discussions and a comparison with physicians' views. Nursing Ethics 2004; 11: 165-78.

16. Westphal DM, McKee SA. End-of-life decision making in the intensive care unit: physician and nurse perspectives. American Journal of Medical Quality 2009; 24: 222-228.

17. Giorgi A. The status of Husserlian phenomenology in caring research. Scandinavian Journal of Caring Science 2000; 14: 3-10. 
18. Champer A, Caritg F, Marquet R. Knowledge and attitudes of health professionals in primary care teams about the document of living wills. Atención Primaria 2010; 42: 463-469.

19. Morse JM, Richards L. README FIRST for a User's Guide to Qualitative Methods. Thousand Oaks, CA: Sage Publications, 2002.

20. Blasco A, Caritg F, Marquet R. Knowledge and attitudes of primary care professionals on the "live wills" document. Atención Primaria 2010; 42: 463-469.

21. Manias E. Australian nurses' experiences and attitudes in the 'do not resuscitate' decision. Research in Nursing and Health 1998; 21: 429-441.

22. Jevon P. Do not resuscitate orders: the issues. Nursing Standar 1999; 13: 45-46.

23. Hildén HM, Palo J. Living wills among hospital patients. Proceedings of the $13^{\text {th }}$ World Congress on Medical Law, 6-10 August 2000, Helsinki, Finland: 474-475.

24. Danis M, Southerland LI, Garrett JM, et al. A prospective study of advance directives for life-sustaining care. New England Journal of Medicine 1991; 324: 882-888.

25. Ewer MS, Taubert JK. Advance directives in the intensive care unit of a tertiary cancer center. Cancer 1995; 76: $1268-1274$.

26. Teno J, Lynn J, Wenger N, et al. Advance directives for seriously ill hospitalized patients: effectiveness with the patient self-determination act and the SUPPORT intervention. Journal of American Geriatric Society 1997; 45: 500-507.

27. Downe-Wamboldt B, Butler L, Coughlan S. Nurses' knowledge, experiences, and attitudes concerning living wills. Canadian Journal of Nursing Research 1998; 30: 161-175.

Received: May 2, 2012

Accepted: July 22, 2012 